\title{
PENGEMBANGAN MODEL PUBLIC MONITORING SYSTEM MENGGUNAKAN RASPBERRY PI
}

\author{
Bambang Yuwono ${ }^{(1)}$, Simon Pulung Nugroho ${ }^{(2)}$, Heriyanto ${ }^{(3)}$ \\ Program Studi Teknik Informatika \\ Universitas Pembangunan Nasional "Veteran" Yogyakarta \\ Jl. Babarsari 2 Tambakbayan Yogyakarta 55281 \\ e-mail : $\underline{\text { bambangy@gmail.com }}{ }^{(1),}$ simonpulung@gmail.com ${ }^{(2)}$, \\ mr heriyanto skom@yahoo.com ${ }^{(3)}$
}

\begin{abstract}
Abstrak
Keterbatasan perangkat pengolah data adalah bentuknya yang cukup besar sehingga kurang flexible dalam fungsi mobile. Raspberry $\mathrm{Pi}$ adalah sebuah komputer papan tunggal (single-board computer) atau SBC berukuran kartu kredit. Raspberry Pi telah dilengkapi dengan semua fungsi layaknya sebuah komputer lengkap, menggunakan SoC (System-on-a-chip) ARM yang dikemas dan diintegrasikan diatas PCB. CCTV merupakan salah satu perangkat yang diharapkan dapat menekan angka kriminalitas pada area publik. Namun kendala mahalnya biaya instalasi (baik listrik atau network) dan terbatasnya mobilitas penempatan alat menjadikan penggunaan perangkat ini belum maximal. Penelitian ini menawarkan solusi alternatif untuk membenahi permasalahan di atas. Pengembangan Prototipe Public Monitoring System Menggunakan Raspberry Pi merupakan sub penelitian awal dari grand research Integrasi Aplikasi Cerdas Public Monitoring System. Output yang akan dicapai adalah terbangunnya perangkat untuk monitoring sistem yang memiliki design mobilitas yang dapat ditempatkan di berbagai tempat. Dengan penelitian ini diharapkan mampu memberikan wacana pemanfaatan Raspberry Pi untuk membangun monitoring sistem yang murah dan mendukung program hemat listrik pemerintah.
\end{abstract}

Kata Kunci : : raspberry pi, monitoring system, cctv, sistem cerdas, mobility

\section{Abstract}

Limitations of the data processing device is large enough shape so it is less flexible in mobile functionality. Raspberry $\mathrm{Pi}$ is a single board computer (single-board computer) or a credit card-sized SBC. Raspberry Pi has been equipped with all functions like a complete computer, using a SoC (System-on-a-chip) ARM packaged and integrated on the PCB. CCTV is one device that is expected to reduce the crime rate in public areas. But the high cost of installation constraints (either electrical or network) and limited mobility placement tool makes use of the device is not maximal yet. This study offers an alternative solution to fix the above problems. Prototype Development of Public Monitoring System Using a Raspberry Pi is an initial sub-study of grand research Intelligent Application Integration Public Monitoring System. The output will be achieved is to build a device for monitoring systems that have mobility design that can be placed in various places. With this research is expected to provide the use of Raspberry Pi discourse to establish a monitoring system that is inexpensive and power-efficient government support programs.

Keyword : raspberry pi, monitoring system, cctv, sistem cerdas, mobility

\section{PENDAHULUAN}

Kemajuan teknologi menimbulkan dampak peningkatan kebutuhan energi. Disatu sisi peningkatan kebutuhan energi merupakan indikator peningkatan kemakmuran. Namun di sisi lain kebutuan energi yang terus bertambah menimbulkan permasalahan dalam usaha penyediaannya. Menipisnya ketersediaan minyak bumi di Indonesia, merupakan salah satu faktor yang harus diatasi pemerintah. Hal ini terbukti dengan jumlah impor minyak bumi Indonesia pada tahun 2011 yang mencapai sebesar 96.038.997 Barel (Data Ditjen Migas). 
Fakta ini dikuatkan oleh pernyataan Direktur Pengendalian Produksi Badan Pelaksana Kegiatan Hulu Minyak dan Gas Rudi Rubiandini yang mengungkapkan bahwa Kebutuhan BBM saat ini ditaksir mencapai 1,3 juta kiloliter (KL), sementara produksi BBM di Indonesia kurang dari 540.000 barel per hari (bph). Indonesia terpaksa impor sekitar 500.000 bph (www.detik.com).

Keterbatasan ini mendorong untuk memanfaatkan segala sumber daya terbaharukan yang ada di lingkungan. Solar cell merupakan salah satu pilar yang dapat digunakan untuk memenuhi sebagian kebutuhan energi manusia. Meski keterbatasan energi merupakan isu yang mendorong pengembangan solar cell, isu lain yang tidak kalah penting yaitu pengembangan perangkat teknologi yang hemat listrik, rashberry $\mathrm{PI}$ adalah salah satu contohnya. Raspberry Pi adalah PCB komputer mungil komplit dengan CPU \& memori. Karena ukurannya yang kecil, komputer ini dijual dalam kemasan yang mirip kotak kartu nama. Untuk sumber daya, Raspberry Pi menyediakan konektor micro USB. Konektor ini sama seperti yang lazim dipakai di ponsel. Kebutuhan energi yang diperlukan oleh perangkat Rashberry ini sekitar 4 watt/jam, angka ini sangat kecil jika dibandingkan dengan penggunaan PC biasa.

Raspberry $\mathrm{Pi}$ adalah single board komputer seukuran kartu kredit, yang dirancang dengan tujuan mempromosikan pengajaran ilmu komputer. Perangkat tersebut dibangun menggunakan prosesor ARM11. Perangkat ini menggunakan kartu SD untuk booting dan penyimpanan jangka panjang. Menggunakan sistem operasi Linux dengan dukungan bahasa pemrograman python atau PHP. The Raspberry Pi memiliki sistem Broadcom BCM2835 pada sebuah chip ( SoC ), yang mencakup prosesor ARM1176JZF - S $700 \mathrm{MHz}$, Video Inti IV GPU, dan pada awalnya dikirim dengan 256 MB RAM, kemudian ditingkatkan menjadi 512 MB (Selvam \& S.Divya, 2013).

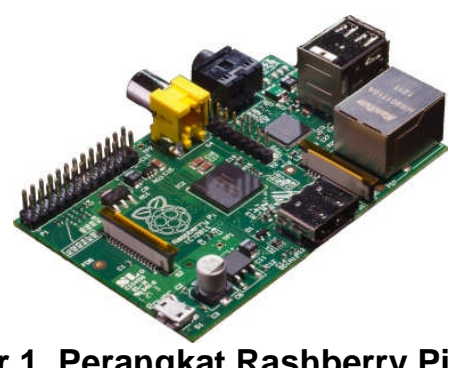

\section{Gambar 1. Perangkat Rashberry Pi}

Selain permasalahan kebutuhan energi saat ini negara Indonesia juga sedang menghadapi tingkat kriminalitas yang cukup tinggi. Hal ini terkait fakta yang disampaikan oleh Wakil Kepala Badan Reserse Kriminal Polri Inspektur Jenderal Polisi Saud Usman bahwa sepanjang tahun 2012 angka kejahatan mencapai 316.500 kasus (Rastika 2012). Adapun salah satu solusi yang dipergunakan untuk menekan angka kriminalitas adalah pemasangan CCTV ( Closed-Circuit Television ) pada area publik yang rawan tindak kejahatan. Namun pemasangan sistem CCTV konvensional memiliki banyak kelemahan, yang antara lain memerlukan instalasi yang rumit, memerlukan perangkat yang mahal terutama untuk komunikasi data ( biasanya memakai VPN ) dan hanya dapat dipasang pada titik-titik tertentu saja. Untuk itu diperlukan model sistem CCTV yang mampu mengatasi keterbatasan yang ada. Ratcliffe et al. (2009) menunjukkan bahwa pemasangan CCTV mampu menurunkan angka kriminalitas hingga 13\% pada lokasi terpasangnya alat tersebut.

Penggunaan sistem CCTV tidak hanya terbatas pada fungsi monitoring. Dengan pengolahan data rekam gambar yang ada, dapat dianalisa dan di kembangkan ke berbagai manipulasi data spasial dan pemodelan visual. Ying et al. (2002) mengembangkan model 3D pada Geographic Information System (GIS) dengan memanfaatkan data-data pada CCTV yang dipasang pada public area. Keunggulan model yang dikembangkan adalah mampu memaximal fungsi dari CCTV untuk memantau fasilitas umum yang ada sehingga lebih terkontrol dalam perbaikan dan perawatannya.

\section{MAKSUD DAN TUJUAN PENELITIAN}

Maksud dari penelitian ini adalah sebagai berikut:

1. Memberikan wacana baru tentang implementasi praktis dari penggunaan perangkat Rashberry Pi 
2. Memberikan model integrasi penggunaan teknologi $3 G$ pada jaringan seluler untuk pengiriman data multimedia.

\section{Tujuan Penelitian}

Produk akhir dari penelitian ini adalah untuk menghasilkan prototype Public Monitoring System yang memiliki keunggulan sebagai berikut :

1. Menggunakan daya listrik sangat kecil

2. Dapat ditempatkan dimana saja karena instalasinya sangat mudah

3. Dapat mengirimkan data monitoring melalui jaringan sehingga data yang terlihat di server bersifat real time

\section{TINJAUAN PUSTAKA}

Beberapa penelitian yang terkait dengan Rasberry $\mathrm{Pi}$ telah banyak dilakukan penelitian oleh Chowdhury, Nooman, \& Sarker (2013) membangun pengontrolan pintu otomatis melalui internet dengan Rashberry Pi. Sistem yang dibangun dilengkapi dengan modul kamera, sehingga wajah orang yang akan masuk ke dalam rumah dapat direkam oleh kamera kemudian dengan koneksi internet dapat mengirimkan data wajah kepada pemilik rumah. Pemilik rumah memeriksa apakah wajah orang yang akan masuk ke dalam rumah merupakan orang yang diijinkan masuk. Jika benar maka pemilik rumah akan memberikan perintah melalui internet ke perangkat pengontrol untuk membuka pintu.

Penelitian lain oleh Joshi \& Gohel (2013) mengembangkan Rashberry Pi untuk perangkat monitoring trafik jaringan karena keunggulannya dalam hal biaya perangkat yang murah, konsumsi listrik yang kecil dan flexiblitas jaringan. Karena perangkat Rashberry Pi menggunakan sistem operasi linux sehingga sangat kompatible dengan tool open source network monitoring system. Pada penelitian ini rashberry Pi digabungkan dengan software ntop sehingga mampu dipergunakan untuk memonitoring lalu lintas data jaringan, status tiap node, status port TCP, UDP, HTTP dan berbagai fungsi lainnya.

Pierce \& Pobprasert (2007) membangun sistem untuk meneliti penyebab kegagalan telur burung. Sistem yang dibangun berupa sistem pengawasan video digital menggunakan kamera inframerah yang berjalan pada 29 fps dan dapat bertahan selama $3 \times 24$ jam. Sistem ini memiliki keunggulan berupa maintenance yang mudah, data digital yang compatible, dan hanya membutuhkan ruang penyimpanan fisik yang kecil sehingga mampu diletakkan dimanapun.

Penggunaan Pan / Tilt kamera yang dapat menyesuaikan gerakan objek, ke atas, bawah, kanan dan kiri merupakan keunggulann jika dipakai dalam sistem monitoring. Namun harga kamera jenis Pan / Tilt sangat tinggi sehingga diperlukan alternative untuk mendapatkan hasil optimal (seperti Pan/Tilt Kamera) dengan menggunakan infrastruktur yang ada. Lim \& Kim (2011) membangun sistem multi-kamera yang memungkin user mampu mengontrol monitoring sistem secara efektif. Penangkapan data image oleh sistem multi-kamera dapat menghasilkan data yang mampu dianalisa untuk memutuskan ada tidaknya gerakan benda dari suatu objek pantau. Analisa tersebut dibangun dengan mengacu data arah gerak, pola arah, deteksi dan jejak objek. Sistem ini juga dilengkapi dengan antar muka yang mampu membantu user menjalan sistem secara remote sehingga kegiatan monitoring dapat lebih efektif.

Monitoring System juga digunakan untuk pengembangan alat pemantau proses deformasi di bendungan Sermo, dimana perangkat yang dipasang terdiri dari 3D Robotic Total Station (RTS), 2 unit CORS GNSS sensor, Automatic Water Level Recording (AWLR) sensor dan Zoom IP Camera. Teknologi GNSS dipasang di dua menara ( menara pertama dan kedua ). Menara pertama telah diinstal penerima GNSS dan Total Station Robotic. Menara kedua telah menjadi penerima GNSS dan 1 titik pemantauan sasaran. Instalasi ini telah berhasil diintegrasikan menjadi sistem otomatis pemantauan deformasi bendungan Sermo (Aris et al. 2012).

\section{METODE PENELITIAN}

Adapun metode penelitian dengan solusi yang ditempuh adalah membangun integrasi Public Monitoring System dengan menggunakan kerangka berpikir sebagai berikut : 


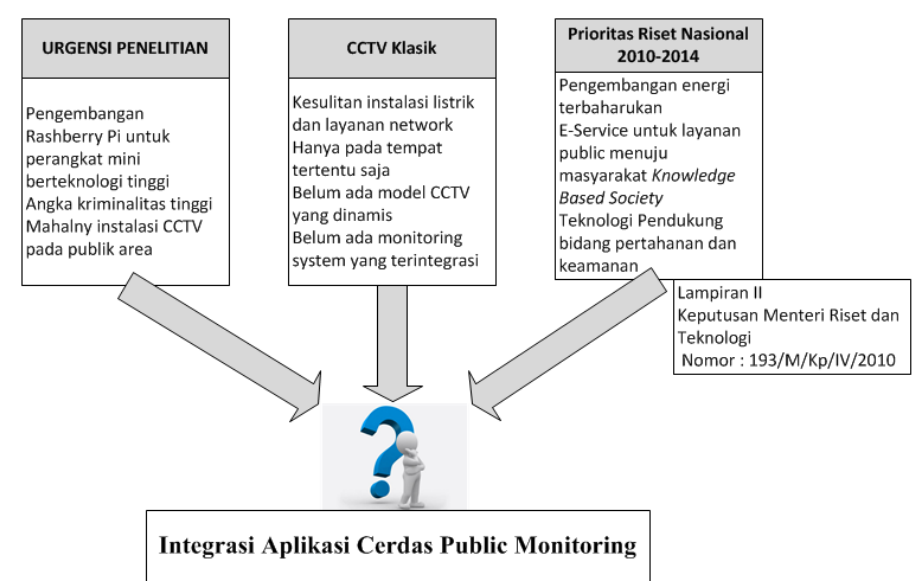

Gambar 2. Kerangka berpikir Public Monitoring System dengan Rashberry Pi

Metodologi yang akan digunakan pada penelitian ini antara lain ; Studi Literatur dan SDLC (System Development Life Cycle) yang meliputi tahap Analysis, Design, Implementation, Testing dan Maintenance, (Pressman, 2002).

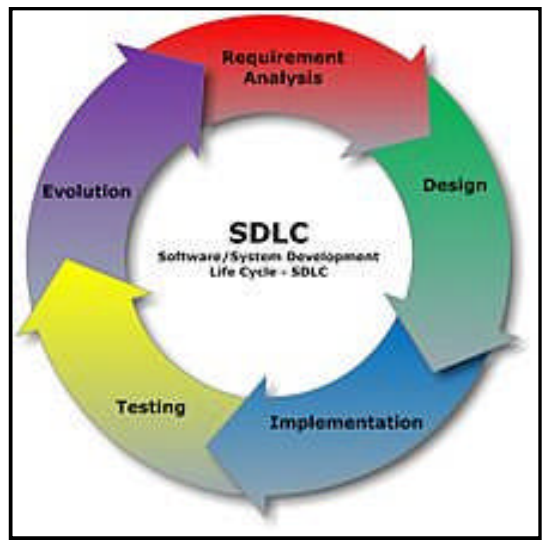

Gambar 3. Bagan tahapan System Development Life Cycle

( Pressman, 2002)

1. Studi Literatur

Tahap ini merupakan tahap pengumpulan informasi dan literatur yang diperlukan untuk pembuatan sistem. Adapun informasi dan literatur yang dipergunakan diantaranya mengenai evaluasi kesesuaian perangkat keras, model topologi jaringan dan mekanisme instalasi perangkat rashberry $\mathrm{Pi}$

2. Analisis dan perancangan

Pada tahap ini dilakukan analisis serta desain yang diperlukan dalam membuat sistem, diantaranya design pemasangan rashberry $\mathrm{Pi}$, model instalasi jaringan, model komunikasi data dan design perangkat lunak monitoring.

3. Implementasi

Pada tahap ini, rancangan sistem yang telah dibuat akan diimplementasikan sesuai dengan design model yang ada.

4. Uji coba dan evaluasi

Pada tahap ini, akan dilakukan uji coba dan evaluasi terhadap sistem serta akan dilakukan perbaikan-perbaikan yang diperlukan.

\section{HASIL DAN PEMBAHASAN}

\subsection{Identifikasi Kebutuhan Perangkat Keras}

Adapun cara kerja alat dimulai dari proses pengisian accu oleh solar cells, kemudian daya listrik yang dihasilkan diteruskan untuk menghidupkan perangkat IP camera, Rashberry Pi dan 
modem. Proses tersebut dilanjutkan dengan penangkapan image di lokasi oleh IP camera, kemudian IP Camera akan mengirimkan data tersebut melewati router dan modem. Data akan dikirimkan melalui internet ke server utama Public Monitoring System, di sistem ini data image diolah.

Pada kajian implementasi awal ditemukan beberapa kelemahan yang sulit diimplemetasikan antara lain sebagai berikut :

1. Percobaan pada penggunaan IP Camera gambar yang dihasilkan kurang bagus sehingga untuk perangkat kamera digantikan dengan penggunaan webcam dengan kualitas gambar yang mampu dimaksimalkan hingga resolusi HD

2. Percobaan pada penggunaan modem untuk komunikasi data pengiriman gambar ke server mengalami permasalahan ketidakstabilan koneksi internet yang diperoleh dari operator seluler, hal ini menyebabkan penuhnya storage pada perangkat rasberry PI sehingga berakibat overload process dan menyebabkan deadlock pada processor. Untuk kendala tersebut solusi yang ditempuh adalah mengganti koneksi via modem 3G dengan koneksi via access point dengan modifikasi penambahan antena grid untuk memperluas jarak koneksi jaringan.

Pengembangan perangkat keras untuk monitoring sistem yang diperlukan sebagai berikut :

1. Solar Cell

2. Web Camera

7. Inverter

3. Antena Grid

8. Accu

4. Access Point

5. Rasberry PI

6. Solar Charge controller

9. Komputer Pesonal dengan processor $2.0 \mathrm{GHz}$.

10. RAM minimal $512 \mathrm{MB}$.

11. $\mathrm{HD}$ minimal $40 \mathrm{~GB}$.

12. VGA minimal $128 \mathrm{MB}$.

Adapun komponen pembentuk sistem Public Monitoring System, sebagai berikut :

1. Solar Cell

Panel surya adalah alat yang terdiri dari sel surya yang mengubah cahaya menjadi listrik, diisebut surya Matahari atau "sol" karena Matahari merupakan sumber cahaya terkuat yang dapat dimanfaatkan. Panel surya sering kali disebut sel photovoltaic, photovoltaic dapat diartikan sebagai "cahaya-listrik".

2. Web Camera

Kamera yang akan diinstall pada sistem rassberry yang akan digunakan untuk menangkap gambar yang nantinya akan dikirimkan ke server untuk diolah pada aplikasi Public Monitoring System

3. Antena Grid

Antena adalah alat untuk mengirim dan menerima gelombang elektromagnetik, bergantung kepada pemakaian dan penggunaan frekuensinya, antena bisa berwujud berbagai bentuk, mulai dari seutas kabel, dipole, ataupun yagi, dsb. Antena adalah alat pasif tanpa catu daya(power), yang tidak bisa meningkatkan kekuatan sinyal radio, dia seperti reflektor pada lampu senter, membantu mengkonsentrasi dan memfokuskan sinyal. Tipe antena grid berfungsi untuk memperkuat dan mengarahkan sinyal wireless untuk melakukan koneksi point to point, multi point, atu sebagai client dai RT/RW NET.

Selain itu antenna berfungsi juga untuk menerima dan mengirim signal data dengan sisitem gelombang radio 2,4 Mhz.Dimana data tersebut bisa dalam bentuk intranet atau internet.

4. Access Point

Perangkat jaringan yang berisi sebuah transceiver dan antena untuk transmisi dan menerima sinyal ke dan dari clients remote.

5. Rasberry PI

Perangkat Rasberry PI merupakan mini komputer yang berukuran sebesar ID Card dan memiliki kemampuan untuk mengolah operasi-operasi logika layaknya komputer PC. Pada sistem ini perangkat rasberry digunakan sebagai controller utama sistem yang bertugas untuk menangkap gambar, mengirimkan gambar ke server, mengatur operasi logika kamera, dan menyimpan meta-data gambar sebagai basis data

6. Solar Charge controller

Fungsi dari Solar Charge controller adalah

a. Mengatur arus untuk pengisian ke baterai, menghindari overcharging dan overvoltage

b. Mengatur arus yang dibebaskan/diambil dari baterai agar baterai tidak full discharge, dan overloading

c. Monitoring temperatur baterai. 
7. Inverter

Inverter adalah perangkat elektrik yang digunakan untuk mengubah arus listrik searah (DC) menjadi arus listrik bolak balik (AC). Inverter mengkonversi DC dari perangkat seperti batere, panel surya / solar cell menjadi AC.

8. Accu

Fungsi accu atau battery adalah menyimpan energi listrik yang diperoleh dari panel surya. Energi listrik yang tersimpan selanjutnya dapat dimanfaatkan sesuai kebutuhan dan berfungsi sebagai cadangan listrik saat malam hari atau saat tidak ada cahaya matahari.

\subsection{Identifikasi Perangkat Lunak}

Untuk perancangan dan implementasi prototype yang akan dikembangkan diperlukan perangkat lunak sebagai berikut :

1. Sistem Operasi yang digunakan adalah Raspbian dan Microsoft Windows 7.

2. Web Server menggunakan Apache 2.2

3. Bahasa Pemograman menggunakan phyton.

4. Database server menggunakan MySQL versi 5.1

5. Web Browser menggunakan Mozila Firefox

6. Tool editor menggunakan netbeans.

7. Tool Database Design menggunakan SQL Yog

\subsection{Sistem Pengiriman data gambar}

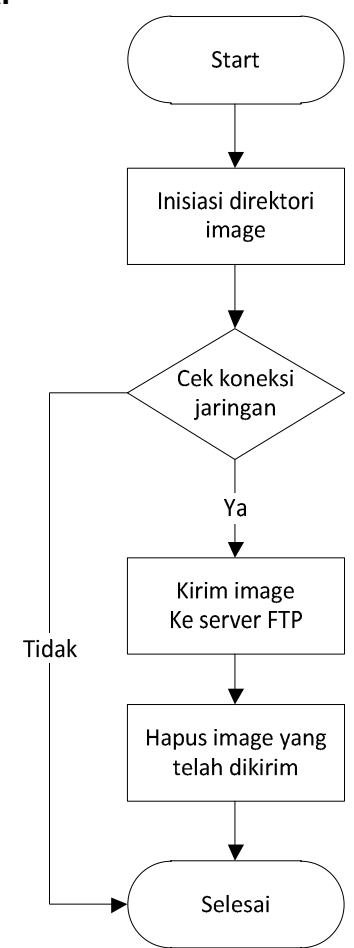

Gambar 4. Flowchart proses pengiriman image ke server 


\subsection{Instalasi perangkat keras}
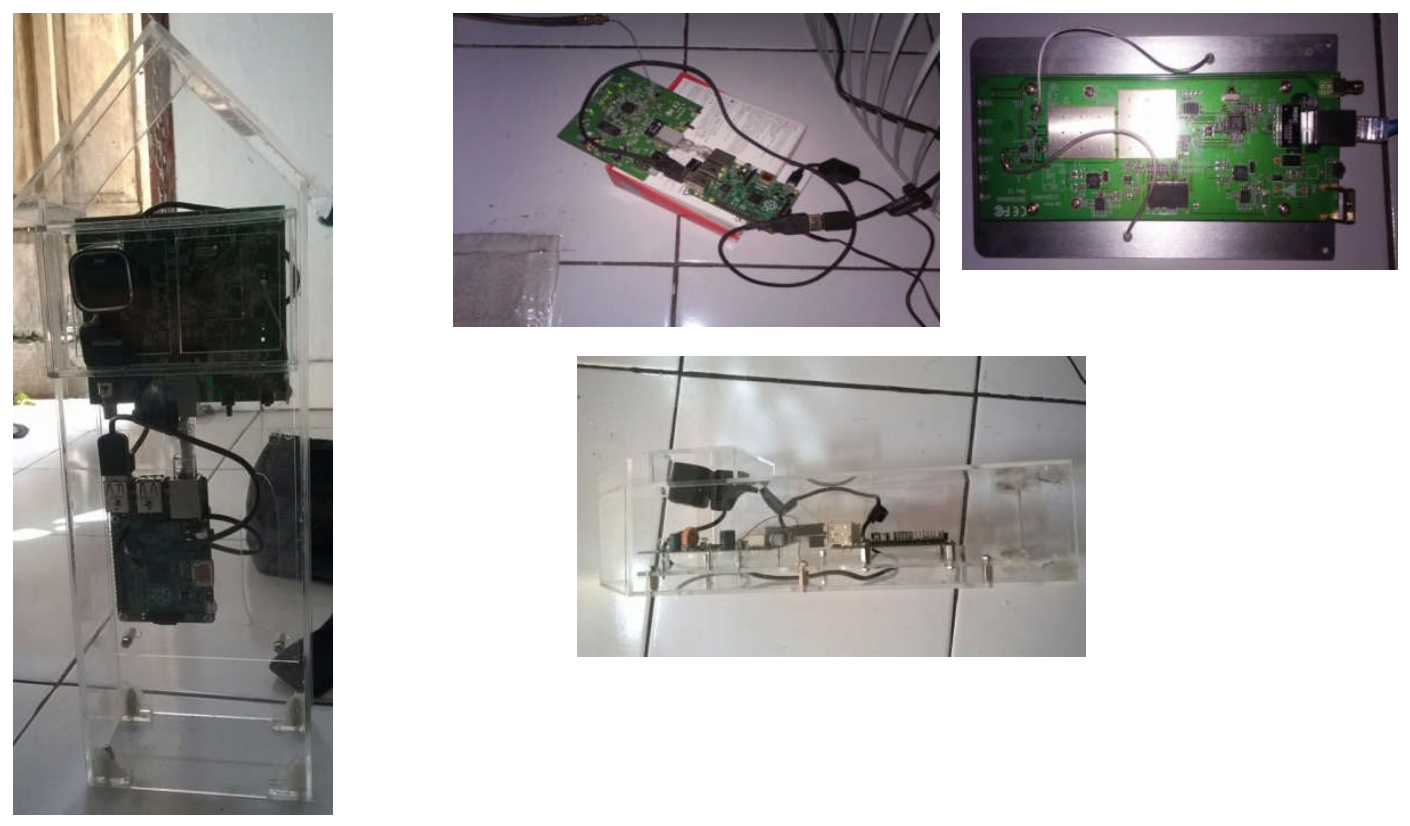

Gambar 5. Instalasi perangkat keras 
5.5 Pengembangan object detection

Pada prototipe ini akan dikembangkan pemodelan untuk deteksi keberadaan manusia pada sistem monitoring. Objek yang tertangkap kamera akan di tandai oleh sistem dengan mark hijau, adapun pada ujicoba awal terlihat hasilnya sebagai berikut.

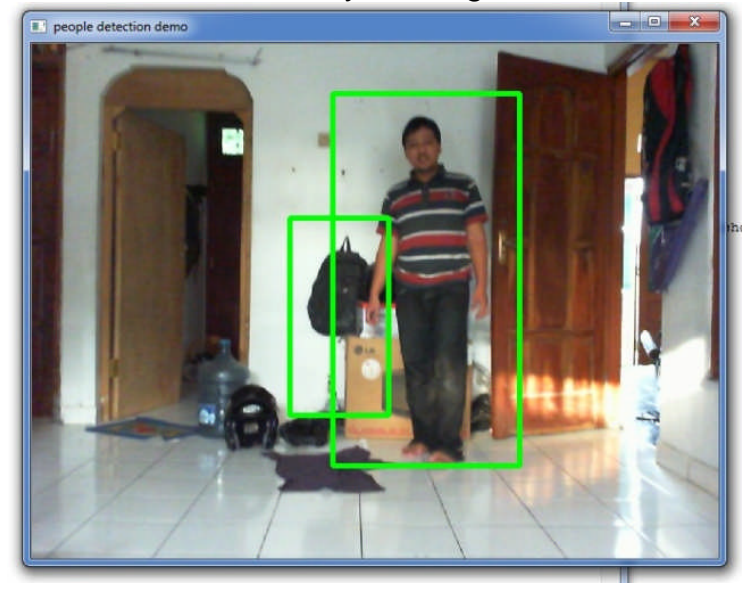

Gambar 6. Object detection

Adapun source code untuk membentuk sistem people detection sebagai berikut :

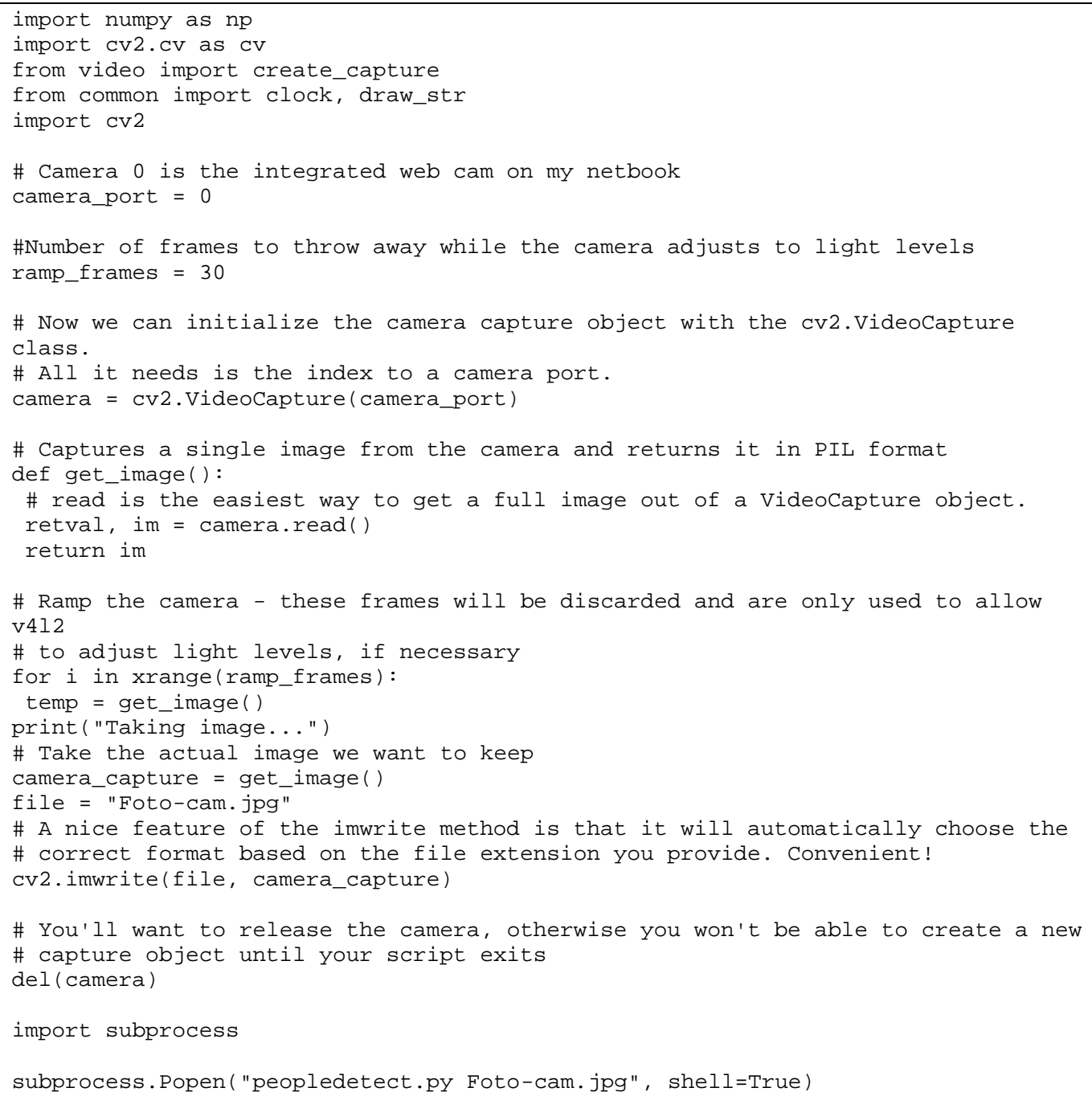




\section{\#peopledetct.py}

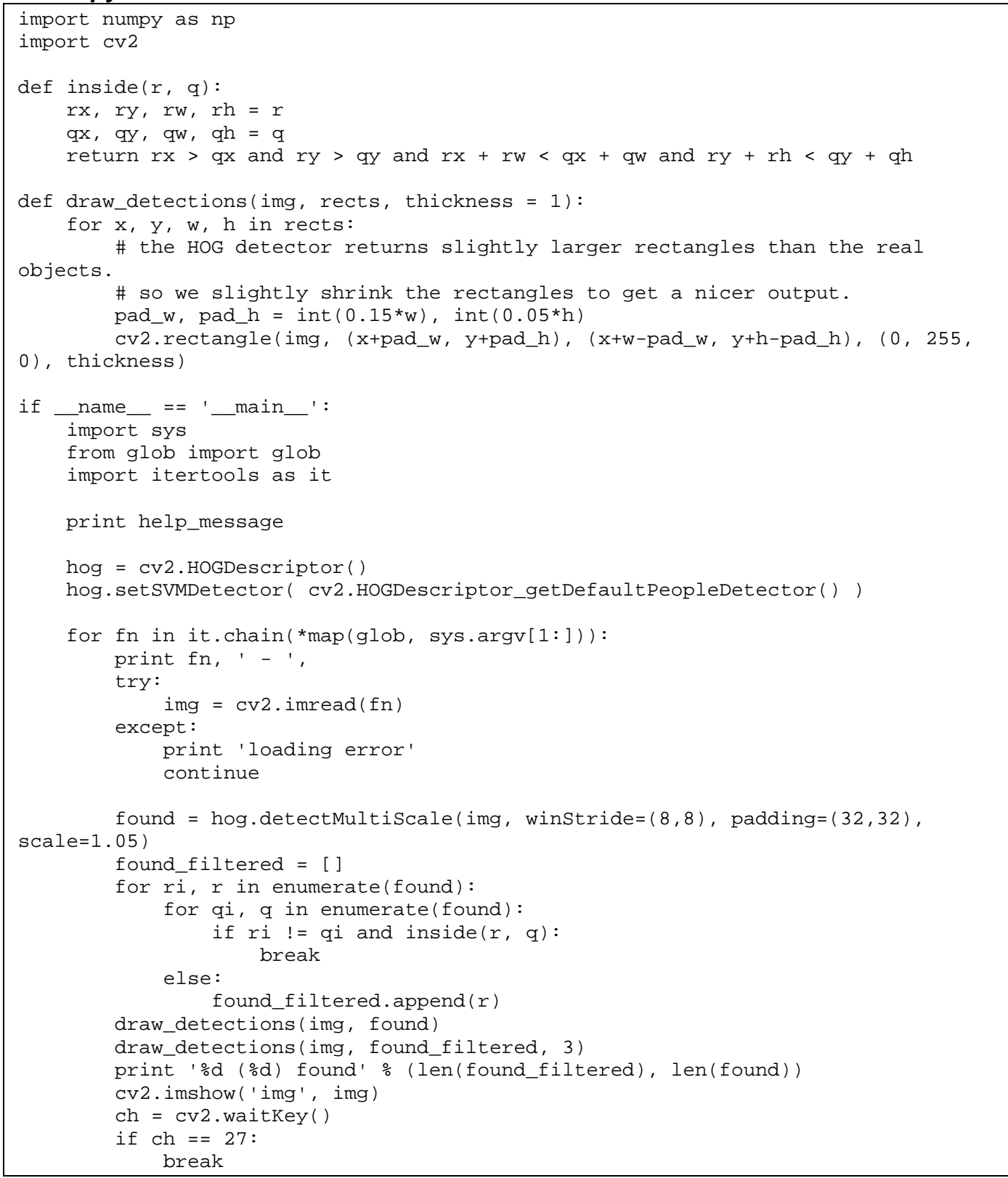

\subsection{Pengujian koneksi jaringan perangkat Public Monitoring System dengan server}

Dalam instalasi perangkat keras sistem ini menggunakan dukungan 2 access point yang dihubungkan dengan metode point to point. Adapun access point yang digunakan adalah indoor access point, hal ini dilakukan selain menekan biaya pembuatan produk adalah untuk mendapatkan perangkat dengan kebutuhan listrik yang minimal nantinya dapat mendukung implementasi solar cell pada sistem ini. Untuk mengatasi keterbatasan jarak jangkauan signal access point yang digunakan, pada sistem ini dimodifikasi dengan menambahkan penguat signal berupa antena grid, sehingga penampakkan awal sistem terlihat sebagai berikut : 


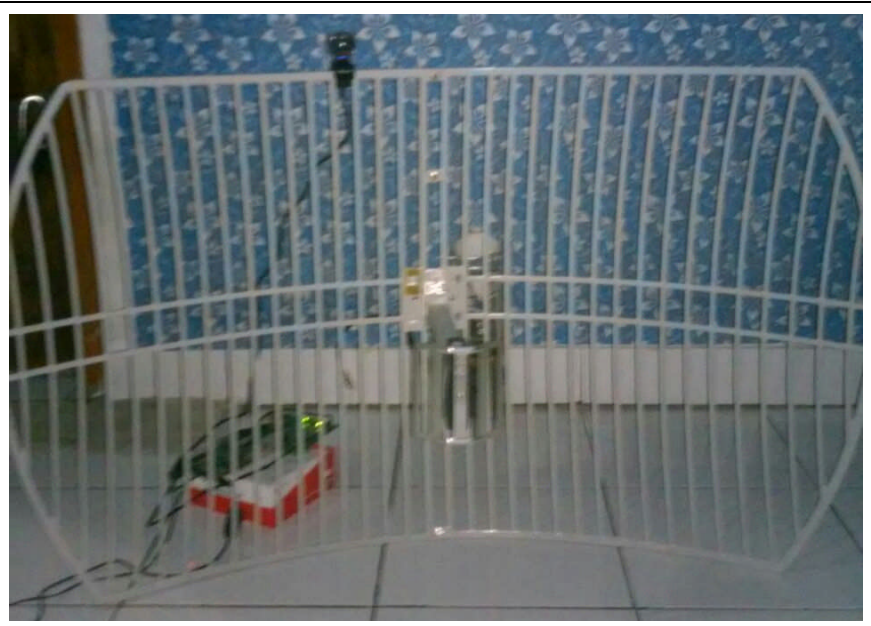

Gambar 7. Access point

Dalam pengujian koneksi jaringan antara perangkat public monitoring sistem dan server, saat dilakukan pengiriman gambar hasil penangkapan dari kamera sebagai berikut :

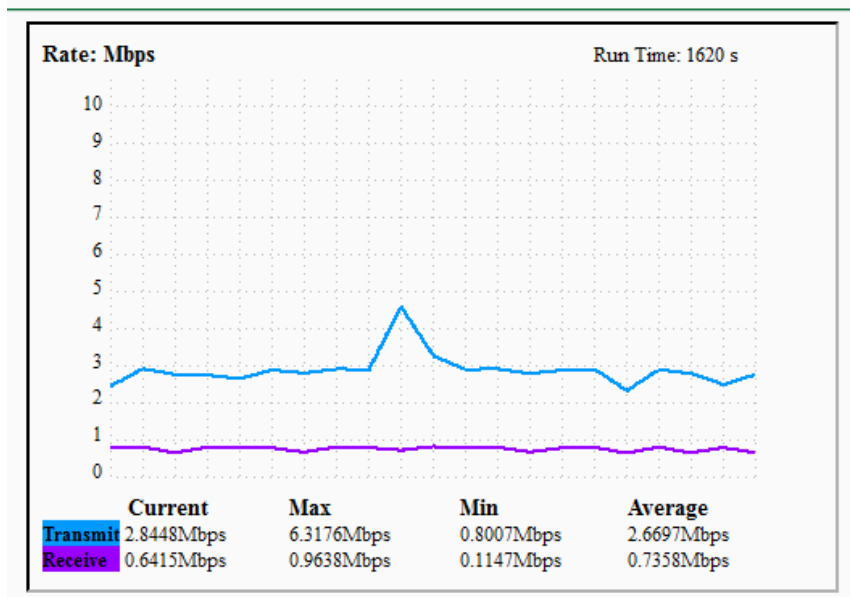

Gambar 8. Hasil Pengujian public monitoring sistem dan server

Terlihat pada hasil pengujian di atas, bahwa koneksi sistem ke server dapat mencapai kecepatan rata-rata sekitar 2,7 Mbps, karena keterbatasan tempat penyimpanan yang dimiliki oleh rassberry PI, untuk mengoptimalkan kinerja, dibuat mekanisme pengelolaan gambar sebagai berikut :

1. Menentukan direktori tempat penyimpanan gambar yang telah diambil oleh kamera

2. Melakukan inisisasi direktori supaya dapat dikenali oleh program

3. Melakukan pengecekkan koneksi jaringan apakah sudah dalam keadaan terhubung atau tidak. Jika tidak terhubung maka program akan langsung terminate atau selesai, namun jika koneksi cek koneksi sukses maka aksi 4 dilakukan

4. Mengirimkan gambar yang ada pada direktori yang telah diinisisasi ke server FTP

5. Jika gambar berhasil dikirim maka file akan dihapus.

\section{KESIMPULAN}

Raspberry Pi telah dilengkapi dengan semua fungsi layaknya sebuah komputer lengkap, menggunakan SoC (System-on-a-chip) ARM yang dikemas dan diintegrasikan diatas PCB. CCTV merupakan salah satu perangkat yang diharapkan dapat menekan angka kriminalitas dengan deteksi keberadaan manusia, dapat didukung dengan daya yang memadai sehingga mendorong untuk memanfaatkan segala sumber daya terbaharukan secara optimal dengan Solar cell. Pengujian koneksi jaringan antara perangkat public monitoring sistem dan server, saat dilakukan pengiriman gambar hasil penangkapan dari kamera bahwa koneksi 
sistem ke server dapat mencapai kecepatan rata-rata sekitar 2,7 Mbps, karena keterbatasan tempat penyimpanan yang dimiliki oleh rassberry PI, untuk mengoptimalkan kinerja, dibuat mekanisme pengelolaan gambar menentukan direktori tempat penyimpanan, melakukan inisisasi direktori supaya dapat dikenali oleh program, melakukan pengecekkan koneksi jaringan apakah sudah dalam keadaan terhubung atau tidak. Jika tidak terhubung maka program akan langsung terminate atau selesai, namun jika koneksi cek koneksi sukses maka aksi dilakukan, mengirimkan gambar yang ada pada direktori yang telah diinisisasi ke server FTP dan jika gambar berhasil dikirim maka file akan dihapus. Adapun aplikasi cerdas Public Monitoring System dengan hasil output yang dicapai adalah terbangunnya perangkat untuk monitoring sistem yang memiliki

1. Design mobilitas yang dapat ditempatkan di berbagai tempat.

2. Pemanfaatan Raspberry $\mathrm{Pi}$ untuk membangun monitoring sistem yang murah dan mendukung program hemat listrik pemerintah.

\section{DAFTAR PUSTAKA}

Aris, S.T. et al., 2012. Design and installation for Dam Monitoring Using Multi sensors: A Case Study at Sermo Dam, Yogyakarta Province, Indonesia . In FIG Working Week 'Knowing to Manage the territory, protect the enviroment, evaluate the cultural heritage. pp. 6-10.

Chowdhury, M. N., Nooman, M. S., \& Sarker, S. (2013, November). Access Control of Door and Home Security by Raspberry Pi Through Internet. International Journal of Scientific \& Engineering Research, Volume 4, Issue 11, pp. 550-558.

Joshi, M., \& Gohel, C. (2013, May). Agent Base Network Traffic Monitoring. International Journal of Innovative Research in Science, Engineering and Technology, pp. 1799-1803.

Lim, J. \& Kim, S., 2011. Design of Multi-camera Based Acts Monitoring System for Effective Remote Monitoring Control. Journal of security engineering, 2, pp.405-412.

Pierce, A.J. \& Pobprasert, K., 2007. A portable system for continuous monitoring of bird nests using digital video recorders. Journal of Field Ornithology, 78(3), pp.322-328. Available at: http://doi.wiley.com/10.1111/j.1557-9263.2007.00119.x [Accessed April 11, 2013].

Rastika, I., 2012. Setiap 91 Detik, Terjadi Satu Kejahatan di Indonesia. http://nasional.kompas.com. Available at: http://nasional.kompas.com [Accessed April 16, 2013].

Ratcliffe, J.H., Taniguchi, T. \& Taylor, R.B., 2009. The Crime Reduction Effects of Public CCTV Cameras: A Multi- Method Spatial Approach. Justice Quarterly, 26(4), pp.746-770.

Available at: http://www.tandfonline.com/doi/abs/10.1080/07418820902873852 [Accessed April 16, 2013].

Selvam, D., \& S.Divya. (2013, December 2). System Design of Raspberry Pi for Radio Frequency Identification and GPS. Vol. 3 , pp. 40-45. 